\title{
PALEOMAGNETISM OF LATE PRECAIMBRIAN KEWEENAWAN IGNEOUS AND BAKED CONTACT ROCKS FROM THUNDER BAY DISTRICT, NORTHERN LAKE SUPERIOR
}

\author{
LAURI J. PESONEN
}

\begin{abstract}
PESONEN, LAURI J. 1979: Paleomagnetism of Late Precambrian Keweenawan igneous and baked contact rocks from Thunder Bay district, northern Lake Superior. Bull. Geol. Soc. Finland 51, 27-44.

A paleomagnetic study was carried out on Late Precambrian (age $\simeq$ $1.1 \mathrm{Ga}$ ) Keweenawan igneous and baked contact rocks from the Thunder Bay region, Northern Lake Superior. Detailed af and thermal demagnetization studies of igneous and baked contact rocks demonstrate that the Middle Keweenawan reversal remains asymmetric throughout the full range of af coercivities and blocking temperatures. Baked contact tests are always positive and the site mean paleodirections do not show streaking. Moreover, the baked rocks yield systematically less scattered paleomagnetic directions than their igneous counterparts, which demonstrates the suitability of baked rocks for paleomagnetic studies. These results show that the asymmetry of the reversal is due to original TRIMs acquired at the time of cooling and thus the asymmetry of remanence directions reflects either apparent polar wandering or non-dipole disturbances during Keweenawan time rather than secondary overprints.
\end{abstract}

Lauri J. Pesonen, 1 University of Toronto, Department of Geology, Toronto, Ontario, Canada.

\section{Introduction}

Late Precambrian Keweenawan igneous activity took place $1.2 .-1.0 \mathrm{Ga}$ ago in the Lake Superior region of the Southern Province of the Canadian Shield (e.g. Halls 1966; Silver and Green 1972). Interest in paleomagnetic work in this region has arisen from the pioneering study of DuBois (1962). He

1 Present address: Geological Survey of Finland Department of Geophysics SF-02150 Espoo 15 Finland showed that through the detection of magnetic reversals, the application of paleomagnetism to Keweenawan rocks could be a powerful tool in stratigraphic correlation. This conclusion has since been confirmed by various authors (e.g. Beck 1970; Palmer 1970; Pesonen and Halls 1977). The Keweenawan data define a prominent anticlockwise movement of the pole known as »The Great Logan Paleomagnetic Loop" (Robertson and Fahrig 1971; Fig. 10). The significance of such loops or »hairpins» (Irving and Park 1972) in the development of Precambrian plate tectonics 


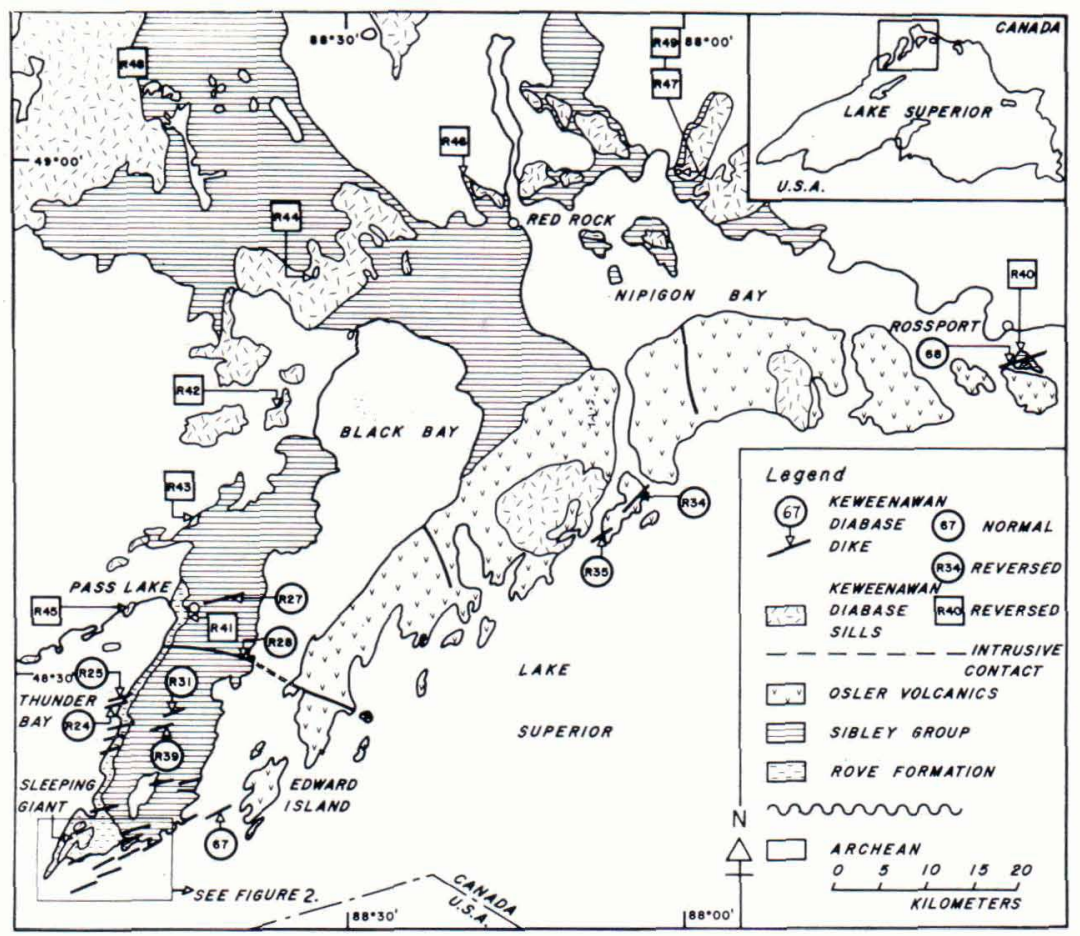

Fig. 1. Simplified geological map of Thunder Bay district showing the $\mathrm{Ke}$ weenawn Logan intrusions and sampling sites. A simple number (e.g. 67) denotes normal polarity (N) and the letter $\mathrm{R}$ denotes reversed polarity. Baked samples were collected at the following sites: R24, R41 (Rove shale): R27, R28, R40, R42, R43，R44，R46，R47， R48 and N67, N68 (Sibley red bed series). For references see Pesonen (1978).

has been discussed by several authors (e.g. Piper et al. 1973), who suggest that they may be the signatures of Wilson-type opening and closing of ancient oceans (Wilson 1966).

A major problem in Keweenawan paleomagnetism is the existence of two asymmetric (i.e. not 180 degrees) reversals (Pesonen 1978): the reversed remanence direction always has a much steeper (upward) inclination than the normal (downward) one (Figs. 4-7). Of particular concern in the interpretation of $\mathrm{Ke}$ weenawan paleomagnetism is whether the asymmetry is caused by a secondary magnetization component (Palmer 1970), by an apparent polar wander (e.g. Beck 1970; Robertson and Fahrig 1971; Pesonen and Halls 1977) or by a fundamental difference in the source region of the geomagnetic field between normal and reversed polarities (Wilson 1972; Pesonen 1978). Previous demagnetization studies of in situ Keweenawan igneous rocks have failed to detect any evidence of a re- gional secondary component which could explain the asymmetry of the reversal (e.g. Palmer 1970; Books 1972; Pesonen and Halls 1979).

The purpose of the present paper is to show, through the use of the baked contact test (Everitt and Clegg 1962; Wilson 1962) and rock magnetic properties, that both normal and reversed directions are due to TRM (thermo remanent magnetization) acquired at the time of magma cooling. This paper and a similar one on dikes from Northern Michigan (Pesonen and Halls 1979) are part of a much larger study on the paleointensity of Keweenawan dikes and their baked host rocks (Pesonen 1978; Pesonen and Halls, in preparation). The demonstration of a TRM is an essential prerequisite for paleointensity determinations. A by-product of the present study includes a new paleomagnetic pole determination for reversely magnetized Logan diabase dikes in the Thunder Bay area. 


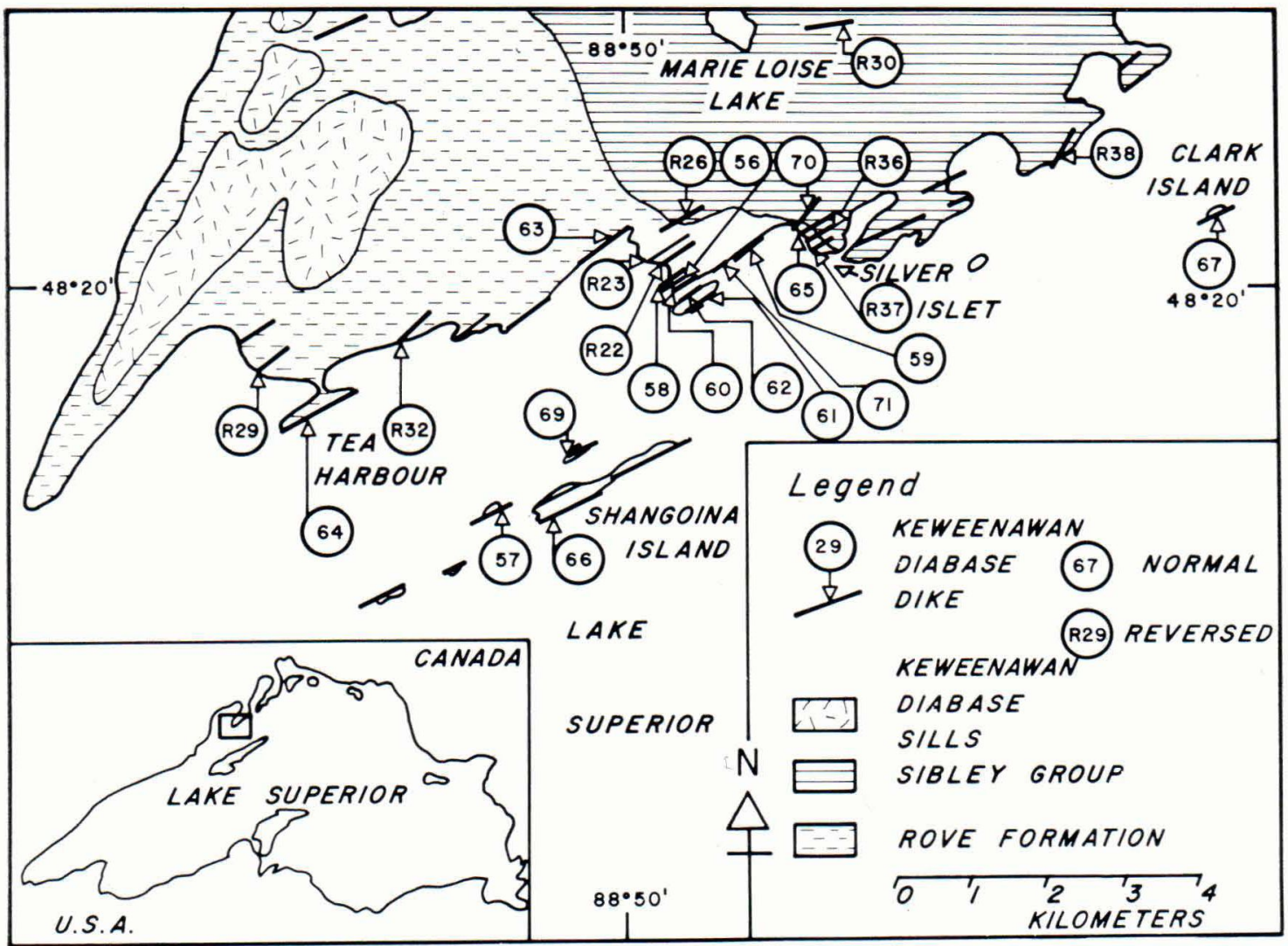

Fig. 2. Simplified geological map of Sibley Peninsula region. Baked contact samples were collected at the following sites: R23, R29, N58, N59, N61 (Rove shale) and R26, R38, N67 (Sibley red bed). Explanation as in Fig. 1.

\section{Geological setting}

The geological setting of the Thunder BayPigeon River (Ontario) area is shown in Figs. 1,2 and 3. The flat-lying Animikean Rove Formation $(2.1-1.6 \mathrm{Ga})$ and the overlying Sibley Series $(\sim 1.3 \mathrm{Ga}$ ) rest unconformably on the Archean (Halls 1966; Franklin et al. 1978; Wanless and Loveridge 1978). Keweenawan diabase sills intrude the Sibley series and the Rove formation. The thickness of the sills varies from a few meters to 300 meters. The sills are horizontal or dip gently to the south.

The Sibley Series and Rove Formation are also cut by predominantly NE- or ENE trending diabase dikes (Figs. 1, 2 and 3). The general strike of the dikes is parallel to the Keweenawan rift axis in the Lake Superior region (Halls 1978). The dikes are vertical or dip steeply to the south and vary in width from 1 to 40 meters. Magnetically these dikes are of both normal and reversed polarity in contrast to the sills, which are of reversed polarity only. From the point of view of paleomagnetic and radiometric age dating, it is important to note that both the normal and reversed dikes cut all the other rock types including the sills (DuBois 1962; Pesonen 1978). Normal dikes are more abundant in the southern tip of the Sibley Peninsula and nearby islands, whereas only reversed dikes 


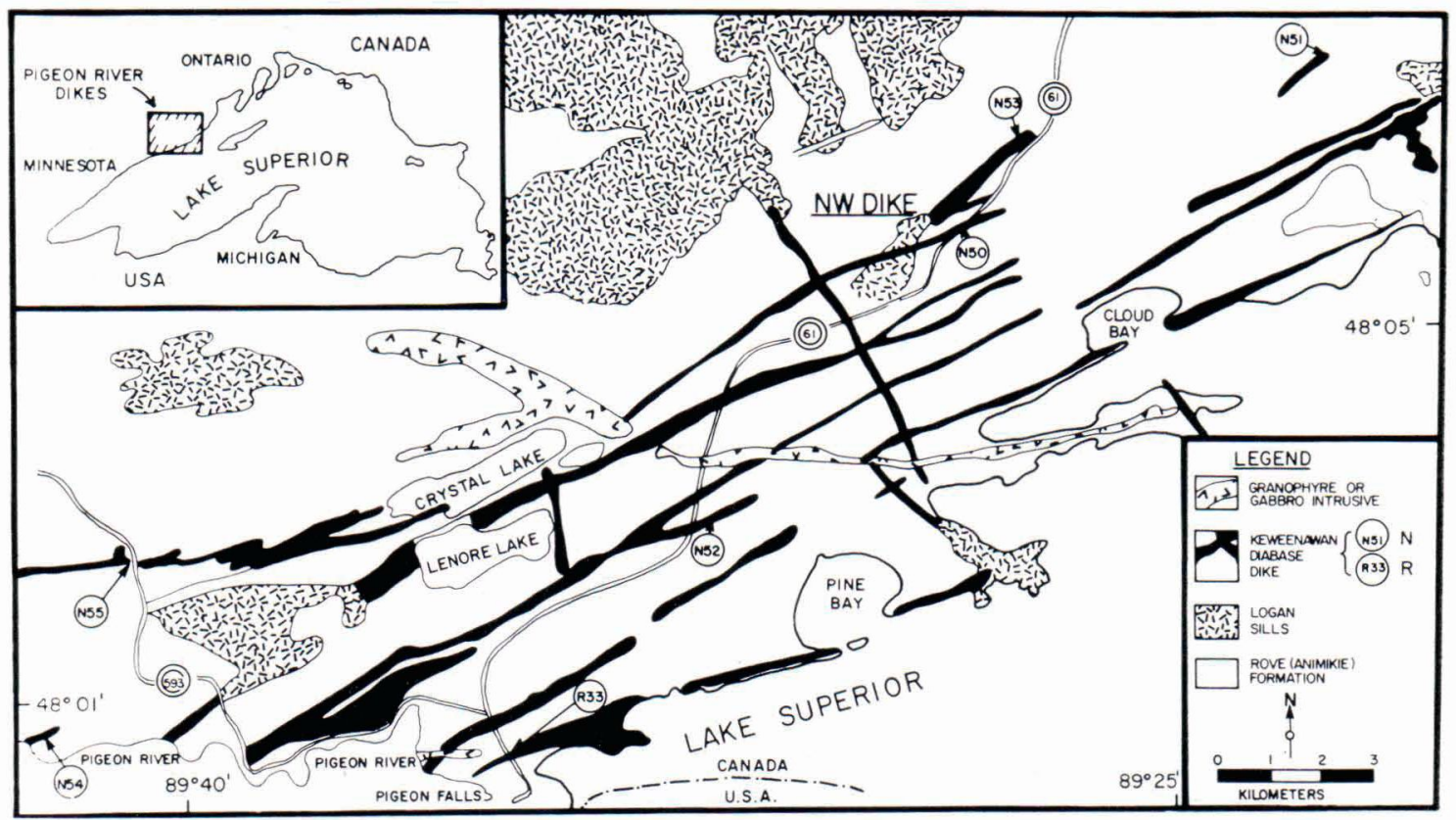

Fig. 3. Simplified geological map of the Pigeon River area showing the Keweenawan dikes. Explanation as in Fig. 1.

have been found north of Marie-Loise Lake (Figs. 1 and 2). According to Mudrey (1976), the reversed sills and dikes are ilmenite-rich tholeiitic intrusions in contrast to the younger normally magnetized olivine bearing diabase dikes. Petrologically these Keweenawan intrusive rocks (also called Logan intrusives) are unaltered or only slightly metamorphosed (DuBois 1962; Robertson and Fahrig 1971; Hanson 1975).

\section{Age of the dikes}

Although geological relationships demonstrate that the ENE-trending dikes are younger than the sills, whole rock K-Ar age data do not reveal any significant age difference between the two rock types (see summary of the age data in Pesonen (1978)). However, the range of $\mathrm{K}-\mathrm{Ar}$ ages is large (730 to $1300 \mathrm{Ma}$ ), suggesting that some argon has been lost. The most recent $\mathrm{Ar}^{40} / \mathrm{Ar}^{39}$ plateau ages (Hanson 1975) suggest an older age $(1175-1147 \mathrm{Ma})$ for the sills than for the dikes $(\simeq 1135 \mathrm{Ma}$ ) which is consistent with geological cross-cutting relations. This trend is supported by a $\mathrm{Rb}-\mathrm{Sr}$ whole rock age $(1200$ $\mathrm{Ma}$ ) for a Rove shale sample baked by a Logan reversed sill (Wanless and Loveridge 1978). According to the available age data and taking into account the complex crosscutting relations (Geul 1973; Pesonen 1978), it is possible that dikes of several ages are present in both polarity groups and that the igneous activity occurred throughout a time interval 1200-1000 Ma ago.

\section{Sampling and laboratory studies}

Two hundred and seventy oriented hand samples (five to twenty per site) were collected from 18 reversed and 22 normal dikes 
and from 10 reversed sills (Figs. 1, 2 and 3). Field orientation was carried out with a suncompass. Baked contact samples were collected at 13 reversed and 5 normal sites (Figs. 1 and 2). In 8 cases the baked country rock is Rove shale whereas in 10 cases it is the Sibley Series. Baked samples were generally obtained from the narrow and often altered (based on colour and texture changes) contact zone to ensure that temperatures in this zone have exceeded $580^{\circ}-680^{\circ} \mathrm{C}$ (Curie temperatures of magnetite and hematite, respectively). This eliminates partially baked rocks with multicomponent NRMs (Robertson 1973). However, at three localities (R24, R27 and R40) samples were collected along profiles extending from the igneous body through the baked zone into the unbaked country rock in order to carry out a fully baked contact test (Everitt and Clegg 1962). A detailed description of laboratory instruments, measuring procedure and paleomagnetic data processing is given by Pesonen (1978).

\section{AF demagnetization studies}

The af demagnetization characteristics of Logan intrusives have been studied earlier by Palmer (1970) and Robertson and Fahrig (1971). They detected only a single characteristic remanent magnetization component in each of the normal and reversed rocks. In this study each specimen was demagnetized in 50-100 oe steps up to 1000 oe. No blanket cleaning was employed in order to carefully monitor possible directional changes at the specimen level. The site-mean directions were also analysed as a function of demagnetizing field (Robertson 1973). This method reduces instrumental noise but must be used with caution (Pesonen 1978). The paleomagnetic stability indices were determined for each specimen using the methods of Symons and Stupavsky (1974) (PSI) and Pesonen and
Halls (1979) ( $\Theta 63)$. Three hundred and fifty igneous and baked specimens were investigated. One reversed dike (R39) and three normal dikes (N69-N71) were excluded from further analysis as they revealed scattered paleodirections caused by unstable NRMs (PSI > 200).

\section{Results}

The majority of the specimens are directionally stable yielding a single characteristic NRM component in agreement with previous studies. Two examples of the dike specimens and adjacent baked contact rocks are shown in Figs. 4 and 5. These examples demonstrate the high directional stability of NRMs (minimum PSI values less than 20) and lack of secondary components, including that due to the present Earth's field (PEF). Note that in both cases the reversal remains asymmetric throughout the full range of the coercivity spectra. Note also that the individual baked specimens tend to yield better paleomagnetic data (smaller PSI values) than their igneous counterparts.

A close investigation of the directional data reveals, however that some of the normal specimens yield a small $\left(5^{\circ} \cdots 15^{\circ}\right)$ directional swing of NRM from a steep positive inclination to a shallower one with westerly declinations. These swings take place at low or moderate fields $(0 \cdots 400$ oe) along a great circle which passes near the PEF direction. Endpoints are attained at higher fields. The swings of the individual specimens are often scattered owing to instrumental noise but this scatter is reduced when site-mean data are investigated (Fig. 6). In contrast to the normal dikes, the reversed ones show no evidence of such swings (Fig. 6). The reversed intensity of NRM, on the other hand, often exhibits an initial increase in low cleaning fields. This is not the case in the normal data 

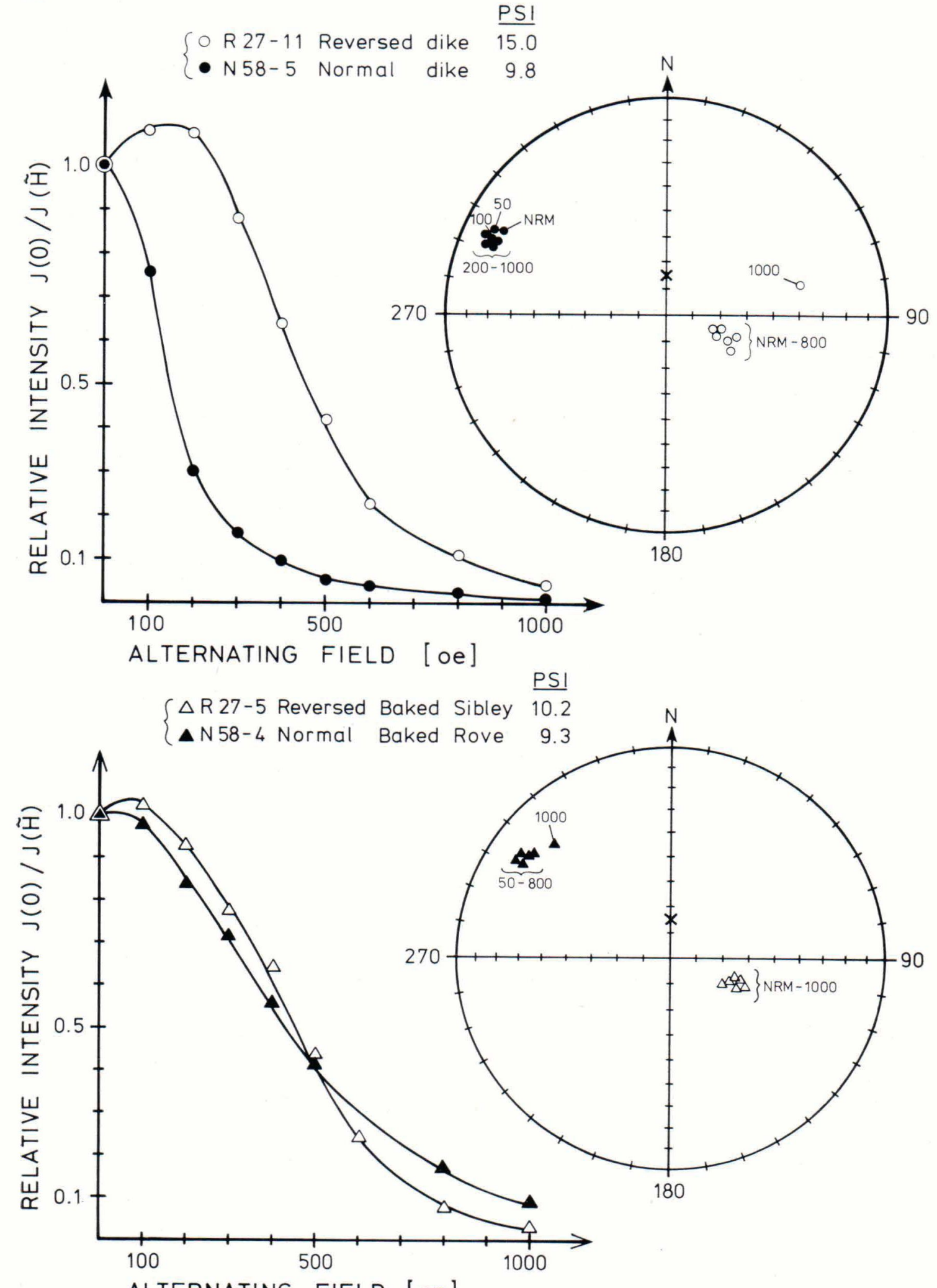

ALTERNATING FIELD [oe] 


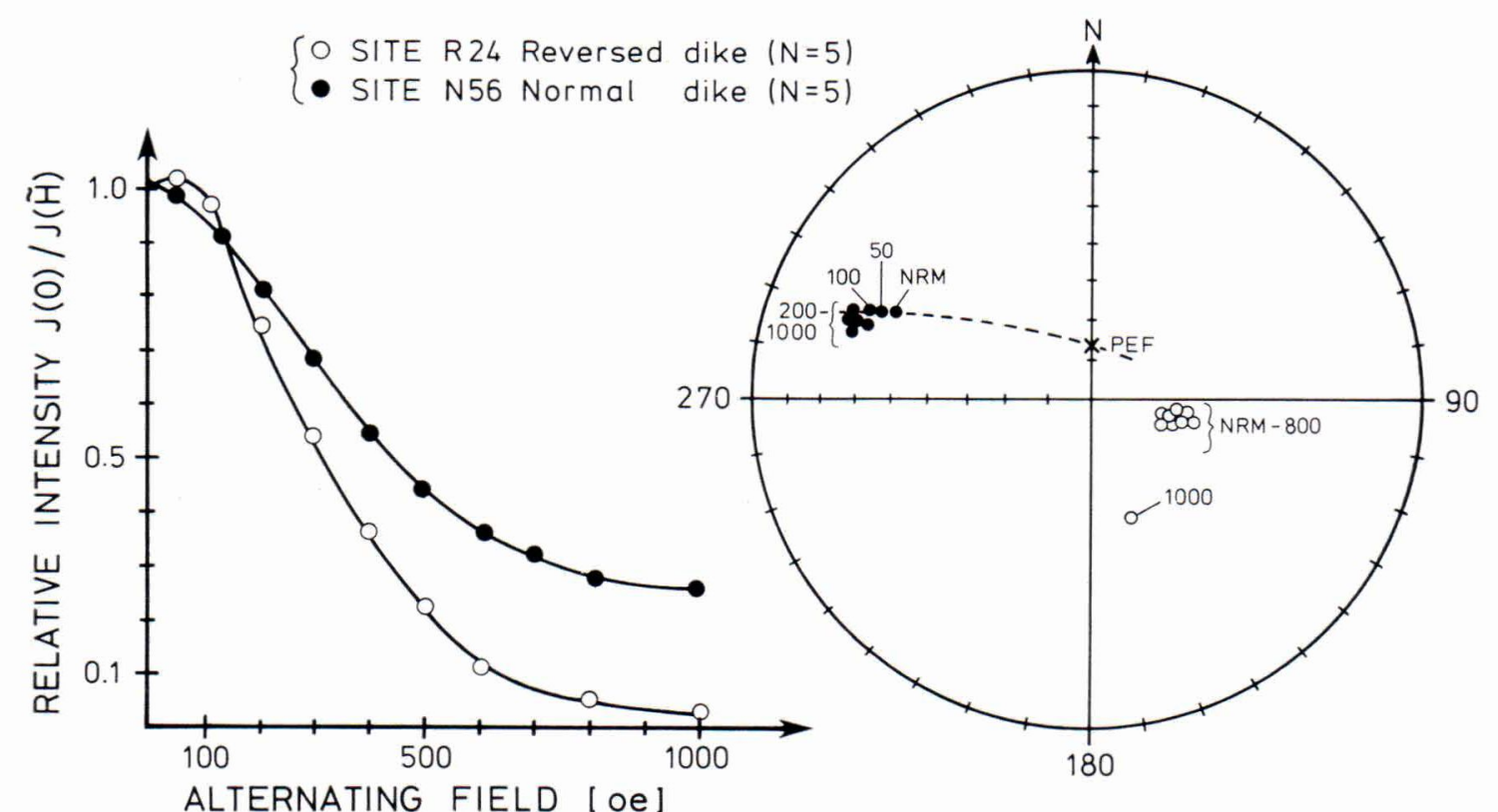

Fig. 6. Examples of the directional swings of site-mean data upon AF demagnetization. Symbols as in Fig. 4. Note that the normal site shows evidence of a small directional swing presumably due to PEF contamination, whereas the reversed one does not.

(e.g. Figs. 4, 5 and 6 ). If a random or selfreversed component were the cause of these swings, the intensity curves of normal and reversed data ought to be similar, which they are not. Therefore, the more likely explanation of the directional swings of the normal data is a superimposed PEF overprint which is almost antiparallel to the steep reversed remanence direction but not to the shallower normal one. The nature of this PEF overprint is probably chemical remanence (CRM) due to recent weathering or viscous remanence (VRM) (Pesonen 1978).

Fig. 4. (opposite, top) Typical examples of AF characteristics of Logan intrusives. Left: normalized intensities of NRM. Right: NRM directions on a Lambert equal-area stereonet. Open (closed) symbol reversed (normal) polarity. (x) denotes the present Earth's magnetic field (PEF).

Fig. 5. (opposite, bottom) Typical examples of AF characteristics of baked contact rocks. Samples taken near the dikes of Fig. 4. Symbols as in Fig. 4.

\section{Thermal demagnetization studies}

The results of thermal demagnetization studies of 210 specimens are comparable to those obtained with af demagnetization. The NRMs of most igneous and baked samples have high directional stability. Two examples of baked specimens are shown in Fig. 7 . Also emphasized in Fig. 7 is the determination of the optimum cleaning temperature with the PSI (Symons and Stupavsky 1974) and $\Theta 63$ (Pesonen and Halls 1979) methods. Note the superiority of the latter method over the former.

In general the reversal remains asymmetric throughout the full range of blocking temperatures up to the hematite Curie-point $\left(680^{\circ} \mathrm{C}\right)$; no evidence of a regional secondary component was found upon thermal cleaning (Pesonen 1978).

Some physical properties of the dikes studied are summarized in Tables 1 and 2 . 

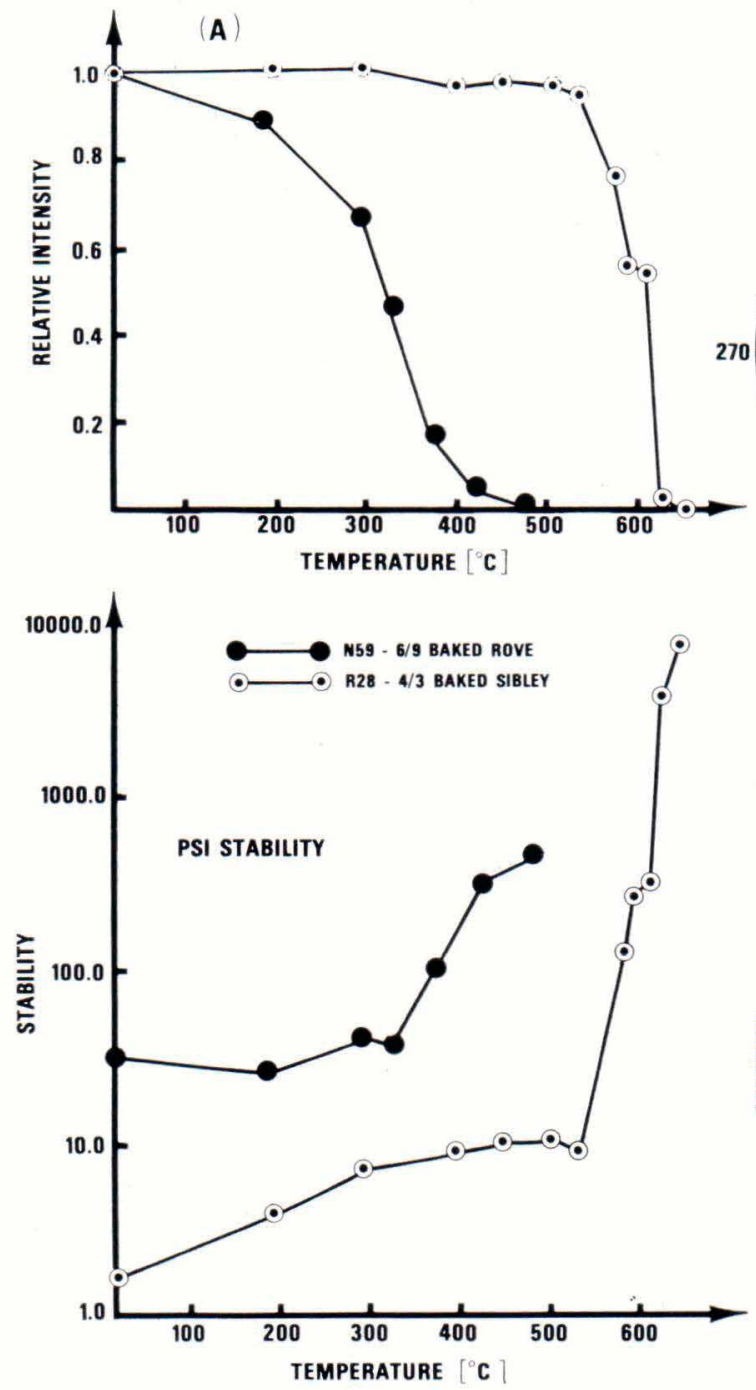

(c)
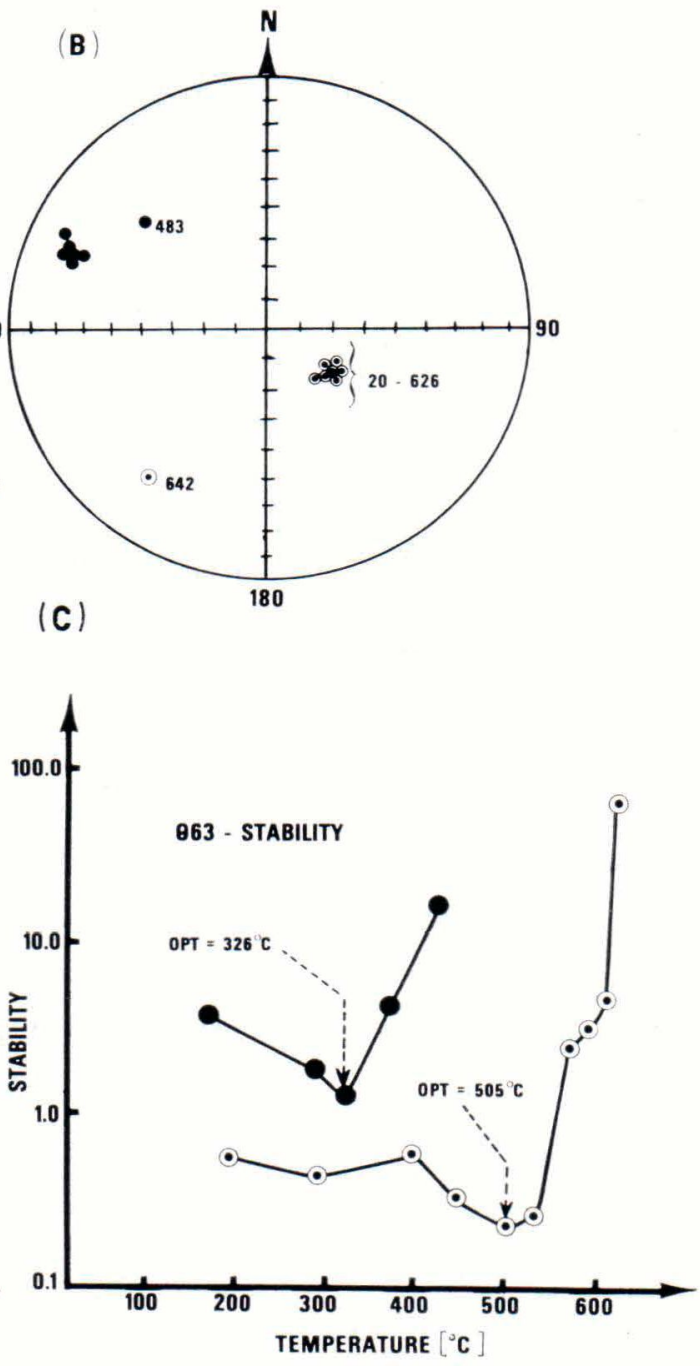

Fig. 7. Two examples of baked contact rocks upon thermal demagnetization. (A) normalized intensities of NRM, (B) directions of NRM on Lambert equal-area stereonet and (C) evaluation of the optimum cleaning temperatures according to the methods of Symons and Stupavsky (1974) (PSI) and Pesonen and Halls (1979) $(\Theta 63)$. Other symbols as in Fig. 4.

An investigation of these data reveals that there is no correlation between the asymmetry of the reversal and rock type, geographic site location or physical properties. If a secondary component is present in variable amounts in these rocks, one might expect to observe a correlation between the inclina- tion and intensity of NRM. No such correlation exists. The magnetic properties of normal and reversed rocks are generally very similar (e.g. $\mathrm{Q}, \mathrm{H}_{1 / 2}$ and $\mathrm{T}_{1 / 2}$ values) except for the tendency of the reversed dikes to have higher susceptibility $(\chi)$ and NRM intensity values than the normal ones (Tables 1 and 2). 
Table 1. Magnetic properties of Thunder Bay normal dikes,

\begin{tabular}{|c|c|c|c|c|c|c|c|c|}
\hline Dike & $\mathrm{N}$ & $\delta$ & $\chi$ & NRM & Q & $\mathrm{H}_{1 / 2}$ & $\mathrm{~T}_{1 / 2}$ & I \\
\hline \multicolumn{9}{|c|}{ Pigeon River dikes } \\
\hline N50 & 5 & 2.94 & 689 & 2001 & 5.0 & 280 & 515 & 45.6 \\
\hline N51 & 4 & 2.94 & 999 & 2898 & 5.0 & 230 & - & 41.9 \\
\hline N52 & 3 & 2.97 & 683 & 1277 & 3.3 & 220 & 445 & 46.2 \\
\hline N53 & 3 & 2.94 & 522 & 2687 & 8.1 & 270 & 459 & 39.4 \\
\hline N54 & 3 & 2.89 & 792 & 2607 & 9.8 & 180 & 430 & 34.8 \\
\hline N55 & 4 & 2.98 & 289 & 2190 & 12.9 & 50 & - & 44.9 \\
\hline Mean & 6 & 2.94 & 662 & 2277 & 7.4 & 205 & 462 & 42.3 \\
\hline \multicolumn{9}{|c|}{ Sibley Peninsula dikes } \\
\hline N56 * & 4 & 2.74 & 104 & 168 & 1.3 & 430 & 460 & 27.2 \\
\hline N57 * & 3 & 2.76 & 22 & 2 & 0.2 & 410 & - & 46.1 \\
\hline N58 * & 5 & 2.87 & 375 & 2071 & 4.6 & 215 & 530 & 17.0 \\
\hline N59 & 1 & 3.00 & 1187 & 2209 & 3.1 & 210 & 500 & 21.3 \\
\hline N60 & 4 & 2.93 & 218 & 472 & 4.1 & 210 & 485 & 19.3 \\
\hline N61 * & 2 & 2.83 & 49 & 30 & 1.0 & 560 & - & 20.8 \\
\hline N62 & 4 & 2.93 & 671 & 1826 & 4.6 & 205 & 500 & 40.1 \\
\hline N63 * & 3 & 2.70 & 33 & 1 & 0.1 & 570 & - & 42.9 \\
\hline N64 & 4 & 2.89 & 329 & 904 & 2.0 & 370 & 485 & 52.0 \\
\hline N65 & 4 & 2.93 & 1053 & 1147 & 1.8 & 80 & 365 & 34.6 \\
\hline N66 & 4 & 3.02 & 598 & 3731 & 8.1 & 160 & 485 & 52.3 \\
\hline N67 * & 2 & 2.80 & 147 & 696 & 18.8 & 230 & - & 46.2 \\
\hline N68 & 2 & 2.93 & 666 & 1125 & 2.9 & 215 & 485 & 39.6 \\
\hline Mean & 13 & 2.87 & 419 & 1106 & 4.0 & 297 & 477 & 35.8 \\
\hline $\begin{array}{l}\text { Mean of all } \\
\text { normal }\end{array}$ & 19 & 2.89 & 496 & 1476 & 5.1 & 268 & 473 & 38.0 \\
\hline
\end{tabular}

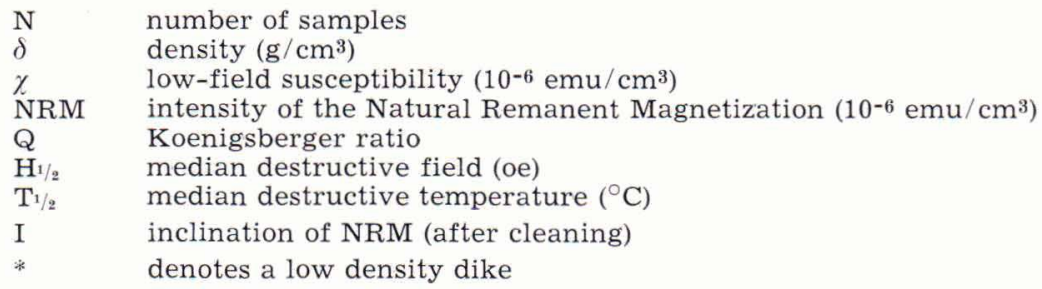

Note: cgs units have been used throughout this work. A useful transformation guide from the cgs system to the SI-system is given in the Appendix

\section{Baked contact tests}

The rationale behind the baked contact test is the fact that the baked country rocks (Rove shale and Sibley red sandstone) have lithological and physical properties different from their igneous counterparts (Tables 1, 2 and 3); hence, it is unlikely that the two rock types have been affected by the same amount of a secondary component, which would result in a negative baked contact test (Everitt and Clegg 1962).

All the baked contact test sites (except sites N68, R40) are in the Sibley Peninsula (Figs 1 and 2). In one case the site consists of a reversed sill (R40) and a normal dike (N68), both intruding the same Sibley unit (Fig. 2). A synthesis of the baked contact tests is given in Table 4 (see also Pesonen 1978). 
Table 2. Magnetic properties of Thunder Bay reversed dikes.

\begin{tabular}{|c|c|c|c|c|c|c|c|c|}
\hline Dike & $\mathrm{N}$ & $\delta$ & $\chi$ & NRM & Q & $\mathrm{H}_{1 / 2}$ & $\mathrm{~T}_{1 / 2}$ & I \\
\hline R22 & 4 & 3.01 & 1510 & 3305 & 3.6 & 310 & - & -66.4 \\
\hline R23 & 3 & 2.94 & 1105 & 6089 & 10.4 & 120 & - & -79.5 \\
\hline R24 & 2 & 2.89 & 673 & 3731 & 9.5 & 310 & 455 & -70.1 \\
\hline $\mathrm{R} 25$ & 4 & 2.85 & 1635 & 1229 & 6.1 & 160 & 465 & -58.6 \\
\hline R26 & 3 & 2.96 & 1136 & 431 & 2.9 & 260 & 485 & -69.0 \\
\hline R27 & 4 & 2.93 & 1144 & 1528 & 2.3 & 480 & 510 & -67.1 \\
\hline R28 & 2 & 2.96 & 873 & 6123 & 11.9 & 150 & 470 & -73.2 \\
\hline R29 & 2 & 2.96 & 426 & 485 & 1.9 & 260 & 495 & -71.4 \\
\hline R30 & 5 & 2.99 & 1201 & 27904 & 35.9 & 250 & - & -64.6 \\
\hline R31 & 2 & 2.88 & 1218 & 747 & 1.0 & 75 & 515 & -68.5 \\
\hline R32 & 4 & 2.99 & 1103 & 762 & 1.4 & 130 & - & -78.1 \\
\hline R33 & 4 & 2.95 & 1282 & 5687 & 7.5 & 350 & - & -60.8 \\
\hline R34 & 3 & 2.98 & 2318 & 3537 & 3.4 & 275 & 465 & -56.9 \\
\hline R35 & 5 & 2.95 & 1616 & 4092 & 4.4 & 430 & - & -57.6 \\
\hline R36 & 3 & 2.98 & 945 & 695 & 1.2 & 280 & - & -65.0 \\
\hline R37 & 3 & 2.95 & 74 & 1885 & 4.0 & 280 & - & -66.5 \\
\hline R38 & 2 & 2.95 & 1398 & 1795 & 1.9 & 110 & - & -62.9 \\
\hline Mean & 17 & 2.95 & 1195 & 4119 & 6.4 & 249 & 483 & -68.4 \\
\hline
\end{tabular}

Same symbols as in Table 1.

\section{Normal polarity dikes}

The mean direction of the NRM of baked rocks after af cleaning $\left(\mathrm{D}=291^{\circ}, \mathrm{I}=31^{\circ}\right.$, $\mathrm{K}=32, \alpha 95=14^{\circ}, \mathrm{N}=5$ sites) agrees well with that of the corresponding dikes $\left(\mathrm{D}=298^{\circ}\right.$, $\mathrm{I}=27^{\circ}, \mathrm{K}=20, \alpha 95=18^{\circ}, \mathrm{N}=5$ ). Thermal demagnetization gives comparable results (Table 4). On the other hand, the direction of the NRM of the unbaked Sibley sediment is very different $\left(\mathrm{D}=252^{\circ}, \mathrm{I}=20^{\circ}\right)$, indicating that the baked contact test is fully positive (Everitt and Clegg 1962).

\section{Reversed polarity dikes}

The mean direction of NRM of the baked rocks after af cleaning $\left(\mathrm{D}=116^{\circ}, \mathrm{I}=-68^{\circ}\right.$, $\mathrm{K}=43, \alpha 95=8^{\circ}, \mathrm{N}=9$ ) is not significantly different from that of the igneous rocks $\left(\mathrm{D}=123^{\circ}\right.$, $\mathrm{I}=-73^{\circ}, \mathrm{K}=40, \quad \alpha 95=8^{\circ}, \mathrm{N}=9$ ). Thermal

Table 3. Magnetic properties of baked and unbaked rocks.

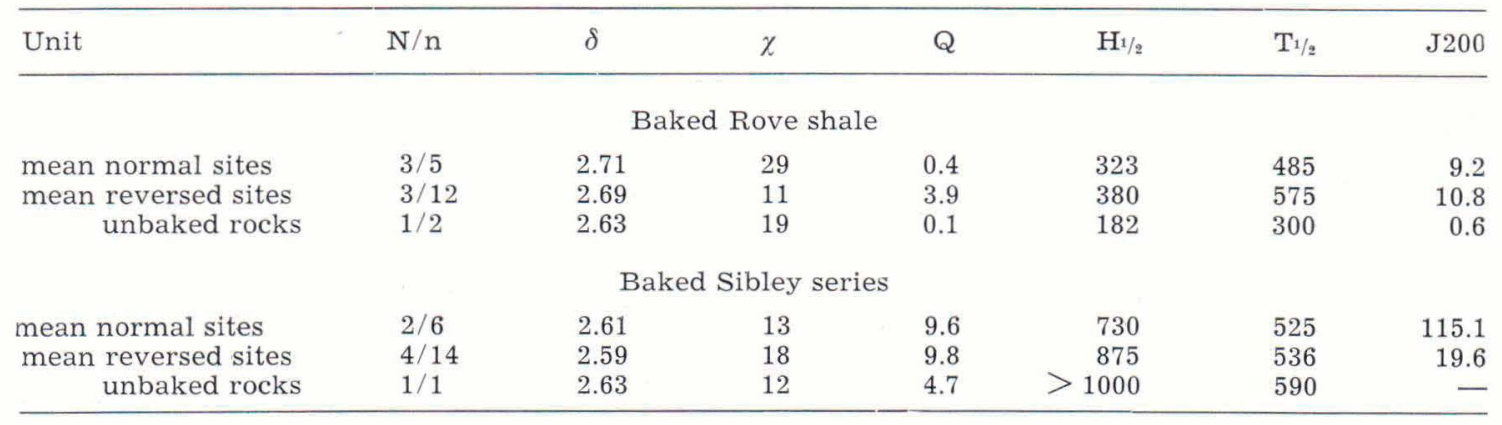

$\mathrm{N} / \mathrm{n}$ number of sites/samples

J200 intensity of NRM after 200 oe af cleaning

other symbols same as in Table 1 
Table 4. Summary of Keweenawan baked contact tests.

\begin{tabular}{|c|c|c|c|c|c|c|c|c|c|c|}
\hline \multirow{2}{*}{ Rock units } & \multicolumn{5}{|c|}{ Af cleaning } & \multicolumn{5}{|c|}{ Thermal cleaning } \\
\hline & $\mathrm{N} / \mathrm{n}$ & $\mathrm{D}$ & I & K & $\alpha 95$ & $\mathrm{~N} / \mathrm{n}$ & $\mathrm{D}$ & I & $\mathrm{K}$ & $\alpha 95$ \\
\hline normal dikes & $5 / 13$ & 298 & 27 & 20 & 18 & $2 / 3$ & 290 & 28 & 38 & 42 \\
\hline normal baked rocks & $5 / 11$ & 291 & $\begin{array}{l}31 \\
20\end{array}$ & 32 & 14 & $2 / 7$ & 294 & 29 & 37 & 42 \\
\hline unbaked Sibley & $1 / 1$ & 252 & 20 & - & - & $1 / 1$ & 245 & 12 & - & - \\
\hline reversed dikes & $9 / 25$ & 123 & -73 & 40 & 8 & $5 / 6$ & 117 & -69 & 24 & 16 \\
\hline reversed baked rocks & $9 / 29$ & 116 & -68 & 43 & 8 & $5 / 14$ & 119 & -68 & 232 & 5 \\
\hline unbaked Sibley & $1 / 13$ & 225 & -2 & 12 & 38 & - & - & - & - & - \\
\hline unbaked Rove & $1 / 5$ & 254 & 48 & 3 & 49 & - & - & - & - & - \\
\hline reversed sills & $4 / 9$ & 105 & -68 & 46 & 14 & $3 / 4$ & 121 & -70 & 63 & 16 \\
\hline reversed baked rocks & $4 / 16$ & 125 & -70 & 181 & 7 & $3 / 9$ & 127 & -73 & 159 & 10 \\
\hline
\end{tabular}

$\mathrm{N} / \mathrm{n}$ number of sites/samples

other symbols same as in Table 1

demagnetization gives similar results (Table 4). In both cases the baked rocks yield less dispersed paleomagnetic directions than the igneous rocks (see $\mathrm{K}$ values in Table 4). This appears to be a characteristic feature of all Keweenawan baked contact tests (Pesonen 1978; Pesonen and Halls 1979) and indicates the particular suitability of baked rocks for paleomagnetic studies (see also Smith 1965). The less dispersed data of the baked rocks results from the higher stability of NRM (smaller PSI and $\Theta 63$ values) of individual baked specimens than of igneous or unbaked specimens (Figs. 4 and 5).

The fully positive baked contact test in reversed data is further emphasized by the NRM results of the unbaked country rocks which are significantly different from those of the igneous and baked rocks (Table 4). The unbaked Rove specimens yield a paleomagnetic direction $\left(\mathrm{D}=254^{\circ}, \mathrm{I}=48^{\circ}\right)$ which is not siginificantly different from that of Books (1972) $\left(\mathrm{D}=241^{\circ}, \mathrm{I}=59^{\circ}\right)$. In contrast, the unbaked Sibley specimens reveal a NRMI direction $\left(\mathrm{D}=225^{\circ}, \quad \mathrm{I}=-2^{\circ}\right)$ in reasonably good agreement with that given by Robertson (1973: $\mathrm{D}=240, \mathrm{I}=16^{\circ}$ ).

\section{Nature of NRM}

Magnetic properties of the baked and unbaked rocks are compared in Table 3 . The magnetic stabilities $\left(\mathrm{H}_{1 / 2}, \mathrm{~T}_{1 / 2}\right)$ and intensities (J200, Q-value) of the baked rocks are an order of magnitude higher than those of the unbaked country rocks. These results, along with the observation that the susceptibilities (which mark the amount of magnetic material) of the country rock types (baked or unbaked) are very similar, strongly suggest that an effective thermoremanence (TRM) was acquired in the baked contact zone at the time of magma intrusion and subsequent cooling (Pesonen 1978). Further support for this idea comes from the profile data of which one example is shown in Fig. 8 (for further profile examples, see Pesonen 1978). In Fig. 8 the NRM directions of the dike (width $\simeq 4.5$ $\mathrm{m}$ ) and adjacent baked contact zone are very similar up to a distance of about 0.6 dikewidth, after which the direction swings progressively towards the unbaked Rove direction. The physical properties (Q-value, relative paleointensity (=J200/A200) etc.) decrease approximately exponentially from the contact. Thus a total TRM is produced 


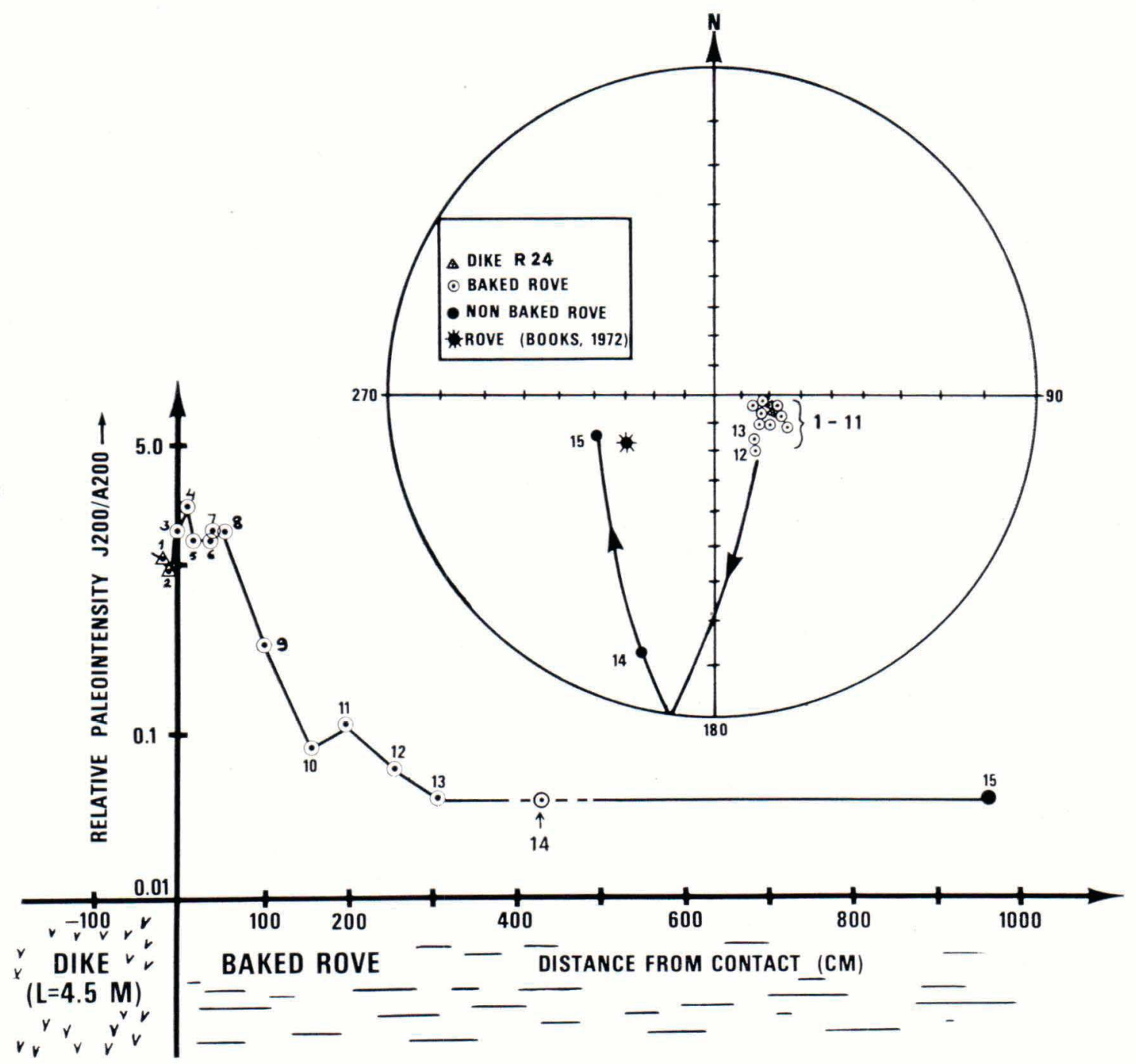

Fig. 8. An example of a paleomagnetic profile across a Keweenawan reversed dike (R24) and Animikeam Rove Formation. Bottom: relative paleointensity (J200/A200), where J200, A200 are the NRM and ARM (anhysteretic remanent magnetization) intensities after 200 oe of cleaning. Top: directions of NRIM (uncleaned). The numbers refer to specimens taken progressively from the contact. (*) denotes the NRM direction of the unbaked Rove formation (Books 1972).

only in a narrow baked zone, whereas a partial TRM is present in the adjacent warmed zone. At a distance of about one to two dike-widths (Fig. 8), the country rock is totally uneffected by the dike intrusion.

The presence of a total TRM in the baked contact rocks is an essential prerequisite for paleointensity studies (Pesonen 1978; Pesonen and Halls, in preparation).

\section{Mean directions and pole positions}

Positive baked contact tests allow us to combine the paleomagnetic data from the 
Table 5. Paleomagnetic results of Thunder Bay normal dikes and baked contact rocks (combined).

\begin{tabular}{|c|c|c|c|c|c|c|c|}
\hline Site & $\mathrm{N}$ & $\mathrm{AF}$ & PSI & D & I & $\mathrm{K}$ & $\alpha 95$ \\
\hline \multicolumn{8}{|c|}{ Pigeon River dikes $\left(\right.$ Lat $=48.1^{\circ} \mathrm{N}$, Long $=89.5^{\circ} \mathrm{W}$} \\
\hline N50 & 5 & $100-200$ & 9 & 305.8 & 45.6 & 423 & 3.7 \\
\hline N51 & 3 & $100-500$ & 12 & 300.3 & 41.9 & 93 & 12.8 \\
\hline N52 & 3 & $200-400$ & 19 & 304.6 & 46.2 & 151 & 10.0 \\
\hline N53 & 3 & $200-400$ & 10 & 305.2 & 39.4 & 69 & 14.9 \\
\hline N54 & 3 & $100-500$ & 18 & 291.0 & 34.8 & 57 & 16.4 \\
\hline N55 & 4 & $200-400$ & 32 & 289.0 & 44.9 & 68 & 11.2 \\
\hline Mean & 6 & & 17 & 299.1 & 42.3 & 131 & 5.8 \\
\hline \multicolumn{8}{|c|}{ Sibley Peninsula dikes $\left(\right.$ Lat $=48.4^{\circ} \mathrm{N}$, Long $\left.=88.7^{\circ} \mathrm{W}\right)$} \\
\hline N56 * & 4 & $200-500$ & 18 & 291.2 & 27.2 & 324 & 5.1 \\
\hline N57 * & 3 & $75-100$ & 123 & 320.0 & 46.1 & 40 & 19.8 \\
\hline N58 * & 6 & $200-500$ & 11 & 296.5 & 17.0 & 74 & 7.8 \\
\hline N59 & 3 & $50-600$ & 13 & 300.8 & 21.3 & 49 & 17.7 \\
\hline N60 & 3 & $200-300$ & 27 & 291.3 & 19.3 & 83 & 13.6 \\
\hline N61* & 3 & $300-800$ & 6 & 294.9 & 20.8 & 145 & 10.2 \\
\hline N62 & 4 & $200-600$ & 16 & 301.5 & 40.1 & 475 & 4.2 \\
\hline N63 * & 3 & $300-500$ & 25 & 321.0 & 42.9 & 52 & 17.3 \\
\hline N64 & 3 & $75-400$ & 12 & 316.2 & 52.0 & 33 & 21.8 \\
\hline N65 & 4 & $150-300$ & 43 & 302.3 & 34.6 & 467 & 4.2 \\
\hline N66 & 3 & $200-1000$ & 12 & 302.4 & 52.3 & 78 & 14.0 \\
\hline N67 * & 5 & $300-600$ & 20 & 280.0 & 46.2 & 65 & 9.5 \\
\hline N68 & 5 & $100-300$ & 14 & 288.9 & 39.6 & 27 & 14.9 \\
\hline Mean & 13 & & 26 & 299.7 & 35.8 & 26 & 8.2 \\
\hline
\end{tabular}

Paleomagnetic pole postition LAT $=34.3^{\circ} \mathrm{N}, \mathrm{LONG}=172.7^{\circ} \mathrm{E}\left(\mathrm{dp}=5.5^{\circ}, \mathrm{dm}=9.5^{\circ}\right)$

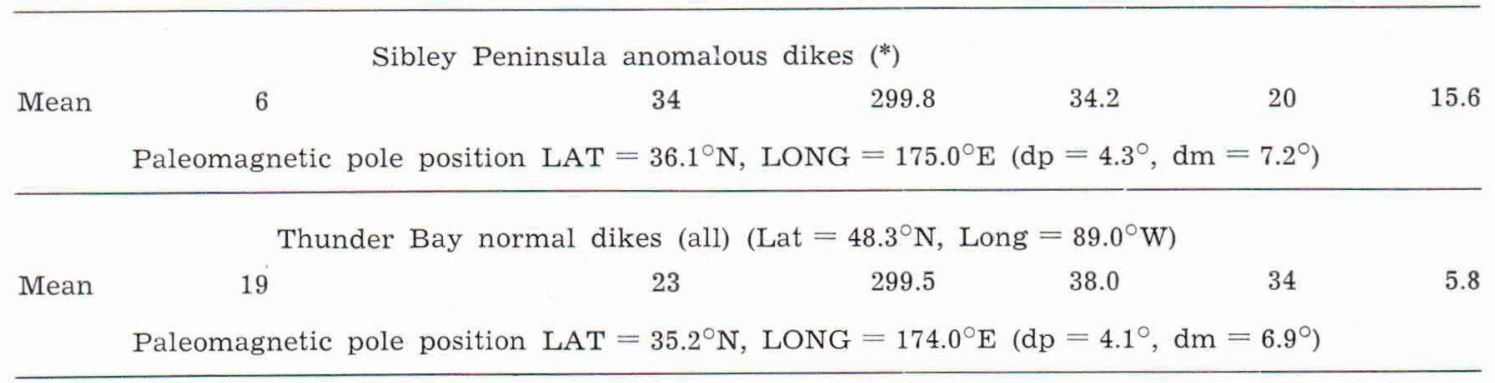

\footnotetext{
* denotes a low-density anomalous dike (see Table 1).

Other symbols as in Table 6.
}

igneous and baked contact rocks in order to calculate the final site mean paleodirections and corresponding paleomagnetic pole positions. The computation procedure is the same as in Pesonen and Halls (1979). We note here in passing that the optimum cleaning (Symons and Stupavsky 1974; Pesonen 1978) and the least-scatter methods (Irving et al 1961) yielded identical paleodirections but that the optimum cleaning method gave smaller scatter (higher $\mathrm{K}$ values). A summary of the paleomagnetic data is given in Tables 5 and 6 and in Fig. 9. The paleomagnetic poles of this work are plotted onto a revised Logan Loop in Fig. 10. (Pesonen 1978).

\section{Normal dikes and baked rocks}

The mean direction of NRM in the Pigeon River normal dikes $\left(\mathrm{D}=299^{\circ}, \mathrm{I}=42^{\circ}, \mathrm{K}=131\right.$, 
Table 6. Paleomagnetic results of Thunder Bay reversed dikes and baked rocks (combined) $\left(\right.$ Lat $=48.4^{\circ}$, Long $\left.=88.8^{\circ} \mathrm{W}\right)$

\begin{tabular}{|c|c|c|c|c|c|c|c|}
\hline Site & $\mathrm{N}$ & $\mathrm{AF}$ & PSI & $\mathrm{D}$ & I & $\mathrm{K}$ & $\alpha 95$ \\
\hline $\mathrm{R} 22$ & 4 & $200-300$ & 14 & 119.6 & -66.4 & 827 & 3.1 \\
\hline $\mathrm{R} 23$ & 4 & $100-600$ & 17 & 113.0 & -79.5 & 47 & 13.6 \\
\hline $\mathrm{R} 24$ & 8 & $200-800$ & 10 & 107.0 & -70.1 & 473 & 2.5 \\
\hline $\mathrm{R} 25$ & 4 & $200-600$ & 28 & 138.0 & -58.6 & 37 & 15.2 \\
\hline $\mathrm{R} 26$ & 6 & $200-500$ & 23 & 116.1 & -69.0 & 47 & 9.8 \\
\hline $\mathrm{R} 27$ & 8 & $100-600$ & 11 & 110.8 & -67.1 & 91 & 5.8 \\
\hline $\mathrm{R} 28$ & 6 & $0-800$ & 9 & 124.3 & -73.2 & 150 & 5.4 \\
\hline $\mathrm{R} 29$ & 5 & $200-400$ & 16 & 119.2 & -71.4 & 271 & 4.6 \\
\hline R30 & 5 & $400-600$ & 33 & 140.5 & -64.6 & 18 & 18.5 \\
\hline R31 & 6 & $300-1000$ & 38 & 118.7 & -68.5 & 8 & 24.7 \\
\hline R32 & 4 & $200-500$ & 80 & 111.9 & -78.1 & 32 & 16.4 \\
\hline R33 & 4 & $100-300$ & 14 & 137.2 & -60.8 & 998 & 2.9 \\
\hline R34 & 3 & $200-400$ & 10 & 110.0 & -56.9 & 108 & 11.8 \\
\hline R35 & 5 & $0-400$ & 11 & 88.8 & -57.6 & 134 & 6.6 \\
\hline R36 & 3 & $200-400$ & 155 & 50.1 & -65.0 & 59 & 16.2 \\
\hline R37 & 3 & $300-400$ & 52 & 75.8 & -66.5 & 130 & 10.8 \\
\hline R38 & 5 & $200-400$ & 34 & 118.0 & -62.9 & 69 & 9.2 \\
\hline Mean & 17 & & 33 & 112.3 & -68.4 & 53 & 4.9 \\
\hline
\end{tabular}

Paleomagnetic pole position LAT $=48.0^{\circ} \mathrm{N} . \mathrm{LONG}=212.2^{\circ} \mathrm{E}\left(\mathrm{dp}=7.0^{\circ}, \mathrm{dm}=8.3^{\circ}\right)$

$\mathrm{N}$

AF

PSI

$\mathrm{D}, \mathrm{I}$

$\mathrm{K}$

$\alpha 95$

LAT, LONG $\mathrm{dp}, \mathrm{dm}$ number of samples

range of cleaning fields of individual specimens (oersteds) paleomagnetic stability index (Symons and Stupavsky, 1974) declination, inclination of NRM

Fisherian precision parameter (Fisher, 1953)

semiangle of the cone of confidence $(\mathrm{P}=0.95)$

latitude and longitude (degrees) of the paleomagnetic pole semiaxis of the oval of confidence of the pole $(P=0.95)$
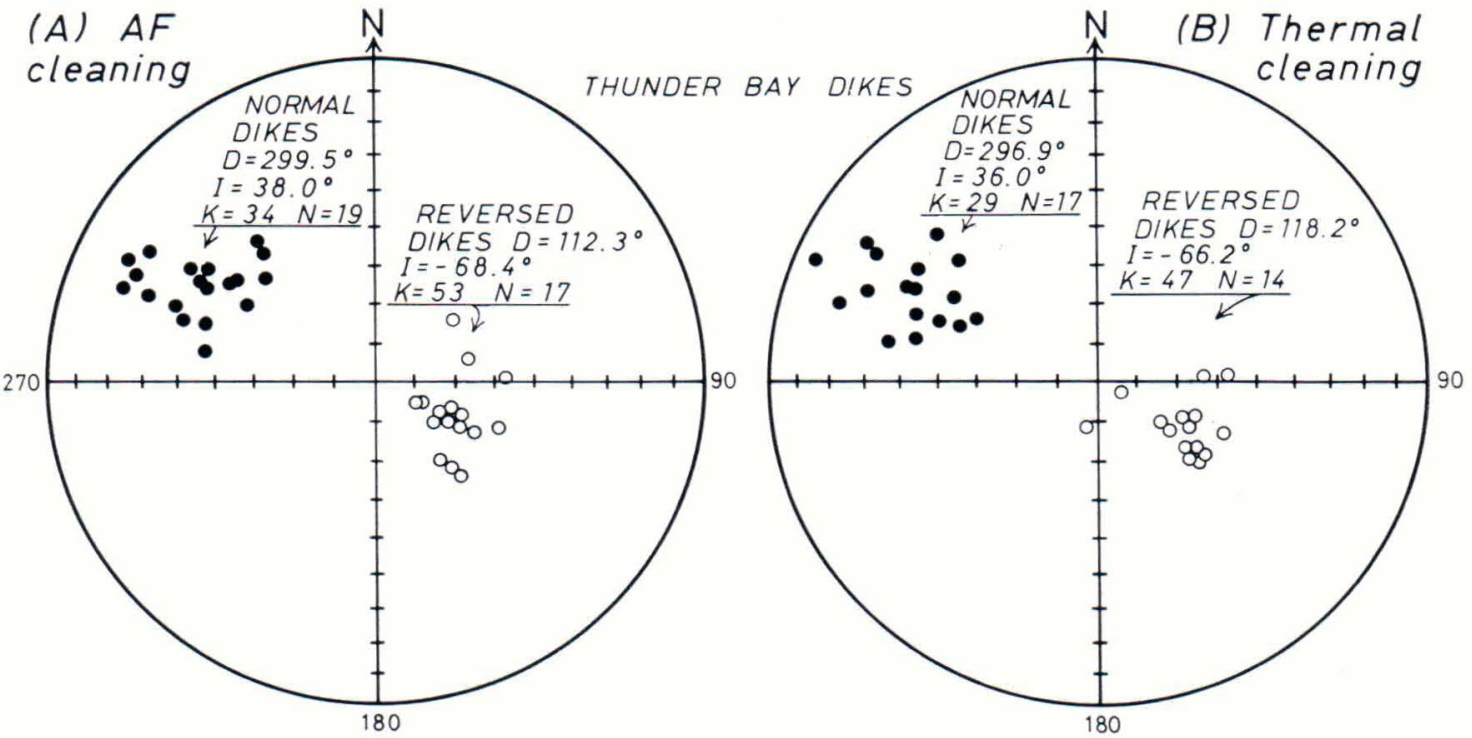

Fig. 9. Summary of paleomagnetic data of Thunder Bay dikes and adjacent baked contact rocks (combined). (A) AF cleaning (B) thermal cleaning. Symbols as in Fig. 4. 


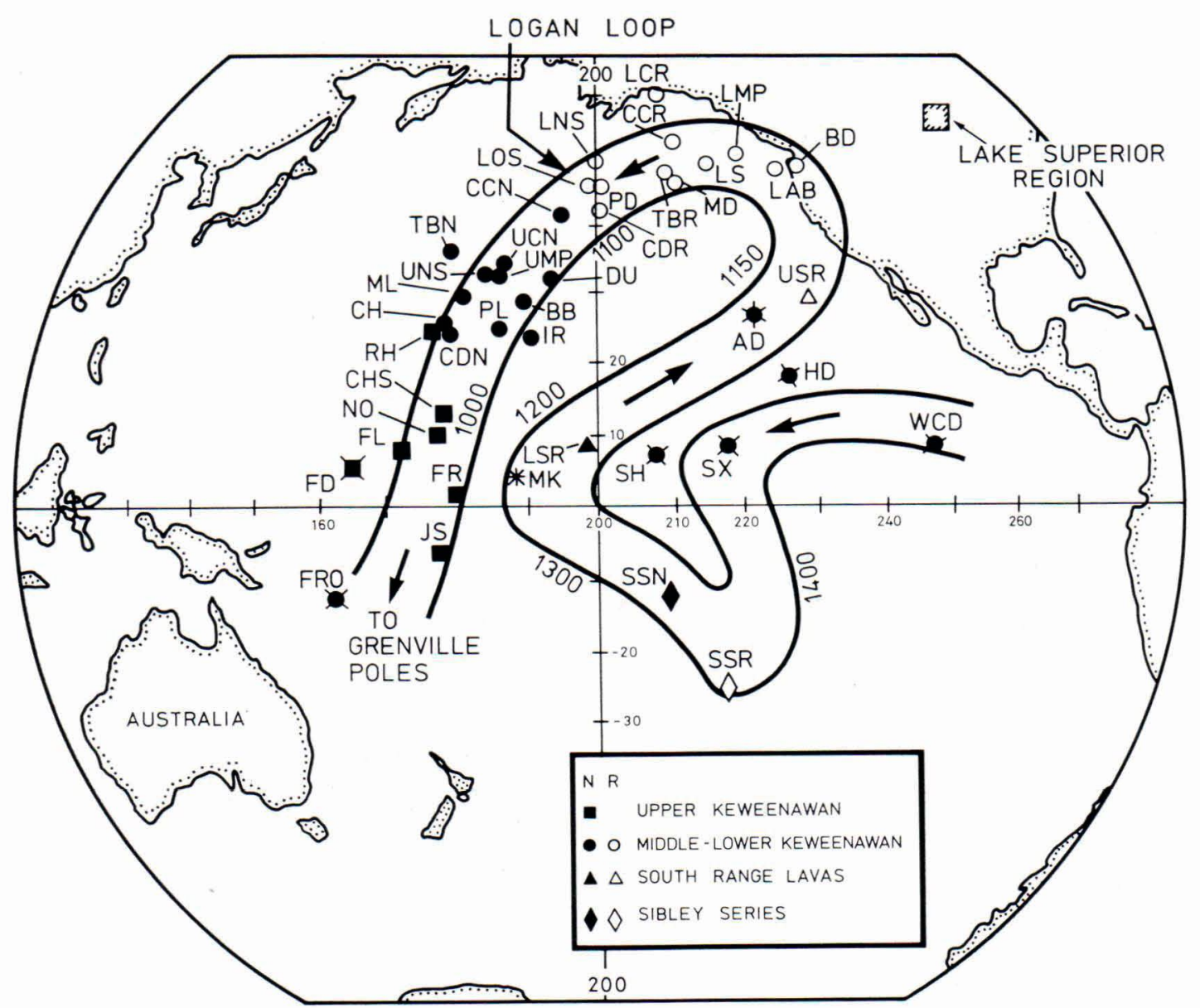

Fig. 10. Paleomagnetic poles of the Logan intrusives and baked rocks (combined) of this work plotted onto the Logan Loop. Data from this work are: TBN (Thunder Bay normal dikes). TBR (Thunder Bay reversed dikes) and LS (Logan reversed sills). MD is the pole for the Lower Keweenawan Marquette dikes of Pesonen and Halls (1979). Open (closed) symbol normal (reversed) pole. For detailed listing of the other symbols and data see Pesonen (1978) and Pesonen and Halls (1979).

$\alpha 95=5.8^{\circ}, \mathrm{N}=6$ ) agrees well with results obtained earlier (DuBois 1962; Robertson and Fahrig 1971). The inclination of the mean remanence direction of the Sibley Peninsula dikes $\left(\mathrm{D}=300^{\circ}, \mathrm{I}=36^{\circ}, \mathrm{K}=26, \alpha 95=8.2^{\circ}\right.$, $\mathrm{N}=13$ ) differs by $10^{\circ}$ from the previous observations. This discrepancy arises from the fact that some of the Sibley Peninsula dikes reveal very shallow inclinations (Tables 1 and 5). DuBois (1962) points out that a few Sibley Peninsula dike samples with anomalous directions may have been hydrothermally altered. Although some of the normal dikes with shallow inclinations $\left(10^{\circ} \cdots 30^{\circ}\right)$ reveal anomalous low densities (see Table 1), they do not appear to be hydrothermally altered dikes. Two observations confirm this view. First, even at these sites, the baked contact tests are positive (Figs. 4 and 5). Secondly, some reversed dikes come from nearby locations without showing any anomalous inclinations or densities. The normal dikes with shallow inclinations presumably represent a slightly younger magnetic pulse than 
the rest of the dikes (Pesonen 1978). This view is supported by the observation of Beck (1969) that there is another group of normal dikes (basaltic dikes) also in Minnesota with shallow inclinations $\left(I \approx 31^{\circ}\right)$, which cut the North Shore lavas of both polarities. However, for lack of further radiometric age data, the anomalous normal dikes are combined with the other normal dikes to yield the overall mean NRM direction and corresponding pole position (Table 5; Fig. 10).

\section{Reversed intrusives and baked rocks}

The mean remanence direction of the reversed dikes and baked rocks (combined) after af demagnetization $\left(\mathrm{D}=112.3^{\circ}, \quad \mathrm{I}=\right.$ $-68.4^{\circ}, \mathrm{K}=53, \alpha 95=4.9^{\circ}, \mathrm{N}=17$ ) is very similar to that of thermal cleaning $(\mathrm{D}=$ $118.2^{\circ}, \mathrm{I}=-66.2^{\circ}, \mathrm{K}=47, \alpha 95=5.8^{\circ}, \mathrm{N}=14$; Pesonen 1978). The site-mean directions do not show streaking (Fig. 9).

The mean remanence direction of the Logan reversed sills and adjacent baked contact rocks after cleaning $\left(\mathrm{D}=112.6^{\circ}, \quad \mathrm{I}=\right.$ $-70.3^{\circ}, \mathrm{K}=55, \alpha 95=4.6^{\circ}, \mathrm{N}=10 ;$ Pesonen 1978 ) is in close agreement with previously published data (Palmer 1970; Robertson 1973).

\section{Discussion}

The paleomagnetic poles of the Logan intrusives studied in this work are shown in Fig. 10, which illustrates the present status of the Logan Loop (see detailed data listing in Pesonen (1978)). The paleopole of the Thunder Bay reversed dikes (pole TBR) $\left(\right.$ Lat $=48.0^{\circ} \mathrm{N}$, Long $=212.2^{\circ} \mathrm{E}, \mathrm{dp}=7.0^{\circ}, \mathrm{dm}=$ $8.3^{\circ}$ ) is virtually identical to that of the Marquette dikes from Michigan (pole MD: Lat $=48.4^{\circ} \mathrm{N}$, Long $=213.5^{\circ} \mathrm{E}, \mathrm{dp}=5.2^{\circ}, \mathrm{dm}=$ $6.2^{\circ}$ ), suggesting that the two dike swarms on the opposite side of the Lake Superior rift axis (Halls 1978) represent the same Lower
Keweenawan igneous activity about $1.1 \mathrm{Ga}$ ago (Pesonen 1978; Pesonen and Halls 1979). On the other hand, the pole position of the Thunder Bay reversed dikes differs only slightly from that of the reversed sills (pole LS) $\left(\right.$ Lat $=49.3^{\circ} \mathrm{N}$, Long $=215.7^{\circ} \mathrm{E}, \mathrm{dp}=9.7^{\circ}$, $\mathrm{dm}=11.2^{\circ}$ ). When both poles are plotted onto the Logan Loop (Fig. 10), the pole of the dikes (TBR) appears in the apparent polar wander interpretation to be slightly younger than the pole of the sills, consistent with geological cross-cutting relations (DuBois 1962; Pesonen 1978). The pole for the normally magnetized dikes (pole TBN) is, however, more than $30^{\circ}$ further along the Loop (towards its younger end) than the reversed poles. The lack of evidence of regional secondary components in detailed cleaning and the positive baked contact test results (Table 4 ) demonstrate that the asymmetry of the reversal $(R \rightarrow N)$ is not caused by regional secondary overprints.

On the other hand, the dispersion of the NRM directions of the reversed dikes $(K=53)$ and sills $(K=55)$ are smaller than that of the normal dikes $(K=34)$ (Tables 5 and 6$)$ after both af and thermal cleaning. Moreover, the same trend is apparent in baked contact rocks, the reversed baked rocks yielding less dispersed (higher $\mathrm{K}$ ) paleodirections than the normal ones (Table 4). These results are consistent with the inclinational (paleolatitude) difference between the two groups of dikes as it is well known that the directional scatter decreases when the inclination (paleolatitude) increases (e.g. Creer 1962). Since it has been demonstrated in this work that both normal and reversed magnetizations are primary TRMs acquired during cooling, the asymmetry of the reversal may reflect an original difference in the inclinations of the paleofield during normal and reversed polarity epochs. Such a difference may be caused by either apparent polar wander or by nondipole geomagnetic field disturbances during Keweenawan igneous activity. To distinguish 
between these two alternatives, future work will be focused on paleointensity and paleosecular variation studies of Keweenawan normal and reversed rocks (Pesonen 1978; Pesonen and Halls, in preparation).

Acknowledgements - The author wishes to thank Drs. H. C. Halls, K. L. Buchan, H. C. Palmer and K. J. Neuvonen for helpful suggestions during preparation of this paper. Dr. W. McIlwai-

\section{References}

Beck, M. E. Jr. (1969) Paleomagnetism and Magnetic Intensities of Keweenawan Intrusive rocks from North-Eastern Minnesota. Ph.D thesis, Univ. of California.

- (1970) Paleomagnetism of Keweenawan intrusive rocks, Minnesota. J. Geophys. Res. 75, 4985-4996.

Books, K G 1972) Paleomagnetism of some Lake Superior Keweenawan rocks. U.S. Geol. Surv., Prof. Pap. 760, 1-42.

Creer, K. M. (1962) The dispersion of the geomagnetic field due to secular variation and its determination for remote times from paleomagnetic data. J. Geophys. Res. 67, 3461-3476.

DuBois, P. M. (1962) Paleomagnetism and correlation of Keweenawan rocks. Geol. Surv. Canada Bull. $71,1-75$.

Everitt, C. W. F. and Clegg, J. A. (1962) A fieldtest of paleomagnetic stability. Geophysical J. $6,312-319$.

Fisher, R. (1953) Dispersion on a sphere. Proc. Roy. Soc. London, A 217, 295-305.

Franklin, J. M., McIlwaine, W. H., Poulsen, K. H. and Wanless, R. K. (1978) Stratigraphy and sedimentation of the Sibley Group. In press.

Geul, J. J. C. (1973) Geology of Crooks Townships, Jarvis and Prince Locations and Offshore Islands, District of Thunder Bay. Ont. Div. of Mines, GR 102, 1-46.

Halls, H. C. (1966) A review of the Keweenawan geology of the Lake Superior region. In: The Earth Beneath the Continents. Am. Geoph. Union, Washington D. C., Geophys. Monog. 10, $3-27$.

- (1978) The Late Precambrian central North American rift system - a survey of recent geological and geophysical investigations. In: Tectonics and Geophysics of continental rifts, ne, Dr. J. Franklin and Mr. H. Poulsen helped to find suitable baked contact sites in the Thunder Bay area. Thanks are due to Dr. H. C. Halls and Mr. J. Hodgson for helping in the field work and laboratory measurements. Mrs. M. Niemi typed the final manuscript and Ms. V. Brody and Mrs. K. Blomster drew the figures. Financial support was obtained through a NRC (National Research Council of Canada) grant to Dr. H. C. Halls (thesis supervisor) and a fellowship by Outokumpu Oy Säätiö (Finland) to L. J. Pesonen.

E. R. Neumann and I. Ramberg Eds., NATO Advanced Study Inst., D. Reidel Publ. Boston, Ser. C, 37, 111-123.

Hanson, G. N. (1975) ${ }^{40} \mathrm{Ar} / 3^{9} \mathrm{Ar}$ spectrum ages on Logan Intrusions, a Lower Keweenawan flow and mafic dikes in Northeastern MinnesotaNorthwestern Ontario. Can. J. Earth Sci. 12, $821-825$.

Irving, E., Stott, P. M., and Ward, M. A. (1961) Demagnetization of igneous rocks by alternating magnetic field. Phil. Mag. 6, 225-241.

Irving, E. and Park, J. K. (1972) Hairpins and superintervals. Can. J. Earth Sci., 9, 13181324.

Mudrey, M. G. Jr. (1976) Late Precambrian structural evolution of Pigeon Point, Minnesota and relations to the Lake Superior syncline. Can. J. Earth Sci. 13, 877-888.

Palmer, H. C. (1970) Paleomagnetism and correlation of some Middle Keweenawan rocks, Lake Superior. Can. J. Earth Sci. 7, 1410-1436.

Pesonen, L. J. (1978) Paleomagnetism, paleointensity and paleosecular variation studies of $\mathrm{Ke}$ weenawan igneous and baked contact rocks. Ph. D. thesis, Univ. of Toronto, $1-375$.

- and Halls, H. C. (1977) Keweenawan asymmetric reversal - secondary component or polar wandering? EOS, Trans. Act. Am. Geoph. Un. 58, 729.

- and Halls, H. C. (1979) The paleomagnetism of Keweenawan dikes from Baraga and Marquette counties, Northern Michigan. Can. J. Earth Sci. (in press).

Piper, J. D. A., Briden, J. C. and Lomax, K. (1973) Precambrian Africa and South America as a single continent. Nature 245, 244-249.

Robertson, W. A. (1973) Pole positions from thermally cleaned Sibley Group sediments and its 
relevance to Proterozoic magnetic stratigraphy. Can. J. Earth Sci. 10, 180-193.

- and Fahrig, W. (1971) The Great Logan Paleomagnetic Loop - the polar wandering path from Canadian Shield rocks during the Neohelikean Era. Can. J. Earth Sci. 8, 1355-1372.

Silver, L. T. and Green, J. C. (1972) Time constants for Keweenawan igneous activity. Geol. Soc. Am., Program with Abstracts, 4, 665.

Smith, P. J. (1965) Tertiary geomagnetic field reversal in Scotland. Earth Plan. Sci. Lett. 1, $341-347$.

Symons, D. T. A. and Stupavsky, M. (1974) A rational paleomagnetic stability index. J. Geophys. Res., 79, 1718-1720.
Wanless, R. K. and Loveridge, W. D. (1978) Rubidium - Strontium isotopic age studies, Report 2 (Canadian Shield). Geol. Survey of Canada, paper $77-14,1-70$.

Wilson, J. T. (1966) Did the Atlantic close and then reopen? Nature. 211, 676-681.

Wilson, R. L. (1962) The paleomagnetism of baked contact rocks and reversals on the Earth's magnetic field. Geophys. J. R. Astr. Soc. 7, 194-202.

- (1972) Paleomagnetic differences between normal and reversed field sources, and the problem of farsided and right-handed pole positions. Geoph. J. R. Astr. Soc. 28: 295-304. Manuscript received, February 2, 1979.

\section{APPENDIX}

Conversion of units from the cgs to the SI system (see also Pesonen (1978)).

\begin{tabular}{lll}
\hline Symbol & Quantity & Units from cgs to SI \\
\hline$\chi$ & magnetic susceptibility & $1 \mathrm{cgs}=1 / 4 \pi \mathrm{SI} \mathrm{units}$ \\
J, NRI & intensity of remanence & $1 \mathrm{emu} / \mathrm{cm}^{3}=10^{3} \mathrm{~A} / \mathrm{m}$ \\
$\mathrm{H}$ & magnetic field & $1 \mathrm{oe}=10^{3} / 4 \pi \mathrm{A} / \mathrm{m}$ \\
$\mathrm{B}$ & magnetic flux density & $1 \mathrm{Gs}=10^{-4} \mathrm{~T}$ \\
Q & Koenigsberger ratio $(=\mathrm{NRM} / \chi \mathrm{H})$ & $1 \mathrm{cgs}=1 \mathrm{SI} \mathrm{unit}$ \\
\hline
\end{tabular}

